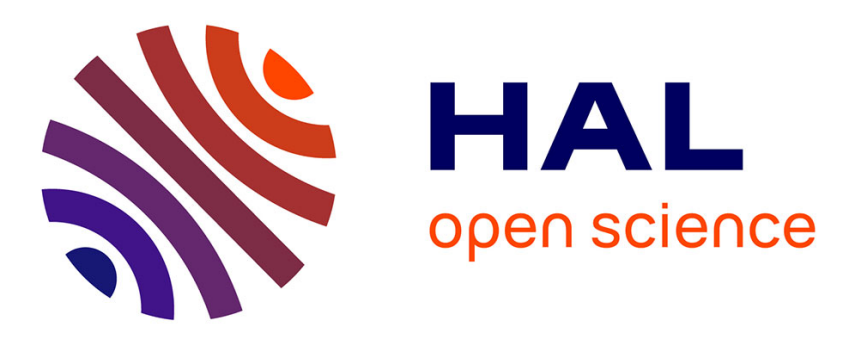

\title{
Data Science-based Sizing Approach for Renewable Energy Systems
}

\author{
Caceres Camilo, Joao Rosario, Mora Jefry, Didier Dumur
}

\section{To cite this version:}

Caceres Camilo, Joao Rosario, Mora Jefry, Didier Dumur. Data Science-based Sizing Approach for Renewable Energy Systems. 2020 IX International Congress of Mechatronics Engineering and Automation (CIIMA), Nov 2020, Cartagena de Indias, Colombia. pp.1-6, 10.1109/CIIMA50553.2020.9290303 . hal-03105070

\section{HAL Id: hal-03105070 https://hal.science/hal-03105070}

Submitted on 10 Jan 2021

HAL is a multi-disciplinary open access archive for the deposit and dissemination of scientific research documents, whether they are published or not. The documents may come from teaching and research institutions in France or abroad, or from public or private research centers.
L'archive ouverte pluridisciplinaire HAL, est destinée au dépôt et à la diffusion de documents scientifiques de niveau recherche, publiés ou non, émanant des établissements d'enseignement et de recherche français ou étrangers, des laboratoires publics ou privés. 


\section{Data Science-based Sizing Approach for Renewable Energy Systems}

\author{
Camilo Cáceres F. \\ School of Mechanical \\ Engineering \\ University of Campinas \\ Campinas (SP), Brazil \\ orcid.org/0000-0003-4540-6584
}

\author{
João M. Rosário \\ School of Mechanical \\ Engineering \\ University of Campinas \\ Campinas (SP), Brazil \\ orcid.org/0000-0002-5347-4029
}

\author{
Jefry Mora M. \\ School of Mechanical \\ Engineering \\ University of Campinas \\ Campinas (SP), Brazil \\ orcid.org/0000-0001-8725-1643
}

\author{
Didier Dumur \\ Département Automatique \\ Centrale Supélec \\ Gif-sur-Yvette, France \\ orcid.org/0000-0002-0474-5080
}

\begin{abstract}
One of the global trends in the energy sector is the inclusion of renewable sources in the grid. This need allows the reduction of greenhouse gases produced by the energetic industry, particularly with the use of fossil fuels and their effects on global warming. Therefore, these implementations need to cover the minimum requirements as balanced energy price, power demand, and a higher ROI, among others, to be reliable and compete with traditional sources. This paper presents a novel approach for sizing a hybrid renewable energy system, using data-driven decisions to meet the demand of a population in Barranquilla city. This method reduces oversizing by optimizing the number of components and increases the whole architecture's energy efficiency by managing the excess or the lack of energy through storage and backup systems.
\end{abstract}

Keywords-Data Science, Data Analytics, Levelized Cost of Energy, PV-Wind based hybrid system (PWHS), Hybrid Renewable Energy System (HRES), Microgrid.

\section{INTRODUCTION}

Nowadays, electricity is a commodity that society became dependant on, almost all activities need it, computers, transport, and illumination are just some examples of this fact. Additionally, the U.S. Energy Information Administration (EIA) projects a $48 \%$ increase in world energy consumption by 2040 [1] while fossil fuels are the primary energy source, are becoming scarce. Consequently, it is necessary to include more renewable and eco-friendly sources in the world energy grid, like solar, wind, tidal, or geothermal energies. Taking into account the world energy consumption in 2018, measured in 161.248 PWh, is technically feasible to obtain 3078 times that quantity using the full potential of renewable sources, where solar covers 2850 times, wind 200 times, biomass 20 times, geothermal five times, tidal two times and hydroelectric one time [2].

One of the main issues of renewable energies is their random nature, which causes a variable generation curve and the need for a backup system that can be an additional source or a storage system. This drawback makes their implementation harder due to the need for a power management component to secure the whole system's correct operation. Hence, to reduce fossil fuel dependency, several experts recommend integrating these renewable sources into the local grid for a bulk generation or through decentralized systems for customer level [3]-[6], taking advantage of their generation potential, their ease of installation, and operation processes.
Once there are two or more energy sources, it becomes mandatory to perform an on-site study to identify the selected sources' behavior and other studies to help in the sizing process. However, the correct design of hybrid architectures is complicated due to the Multiple-Criteria Decision-Making (MCDM) scenario. There are many approaches to provide the "optimal design" criteria, as technical, economic, environmental, and social parameters [7], [8]. Additionally, it is necessary to work with the non-linear characteristic response in the system's components, design constraints, energy management techniques, system topology, among other characteristics [9].

On the other hand, it is essential to use intuitive methods to obtain the first approach to calculating the initial capital investment [10]. Consequently, it is possible to find three different techniques to make a more realistic approach, which works as the correct design basis. The first one is "the annual monthly average," which consists of obtaining the yearly average monthly values of the essential parameters such as radiation, wind speed, or energy demand. The second one is "the most unfavorable month," which consists of obtaining the same values but under the month with the worst behavior like low radiation or high energy demand [11]. The third one is called "Loss of power supply probability (LPSP)," it consists of obtaining the quantity of the components under the reliability of the system, which includes the cost and the probability of loss of energy [12].

Looking for optimal sizing is necessary to consider the characteristics of the problem due to existing many methodologies, which can be categorized into two main groups, classical techniques where are grouped all methods that use a mathematical approach to the optimal solution [13]. This group includes the graphic construction method, which is the oldest and uses the average data of radiation and energy demand, leading to over or under-sizing in some cases [14]. The second one is the probabilistic methods, which are considered the simplest ones; their results may not be the optimal option because it cannot represent the system's dynamic performance but always deliver a secure option [15]. The analytical methods allow the simulation of the resulting configurations' performance in software and obtain the best configuration. Still, they present an obstacle to estimating the position-related equation's coefficient, crucial in these approaches [16].

Implementing hybrid architectures allow an optimal sizing of each renewable energy system, including the storage, due to the number of parameters and topologies that can be tested 
compared with a single source. Nevertheless, none of the current approaches deliver the optimal sizing for all involved parameters; this result will be linked to the optimization criteria [17]. On the other hand, data science is widely used together with big data in smart grids to improve customer service [18], decision-making, reliability, as well as correcting both grid sizing and distribution [19], [20].

Consequently, a different approach combining some sizing methods and employing data-driven techniques can deliver a new sizing methodology. Hence, this paper introduces a datadriven approach to size a PWHS. This proposed methodology is exemplified by Barranquilla's case study and tries to provide energy for a residential zone. The proposed energy harvesting zone corresponds to the city's outskirts of the city $\left(10.9750^{\circ}\right.$, $\left.74.8715^{\circ}\right)$.

\section{PROPOSED DATA-DRIVEN PROCESS}

This work proposes applying the data science life cycle to the design of a renewable energy system sizing. This work's renewable energy system is based on photovoltaic (PV) cells, wind turbines, and a storage system, as Fig 1 shows.

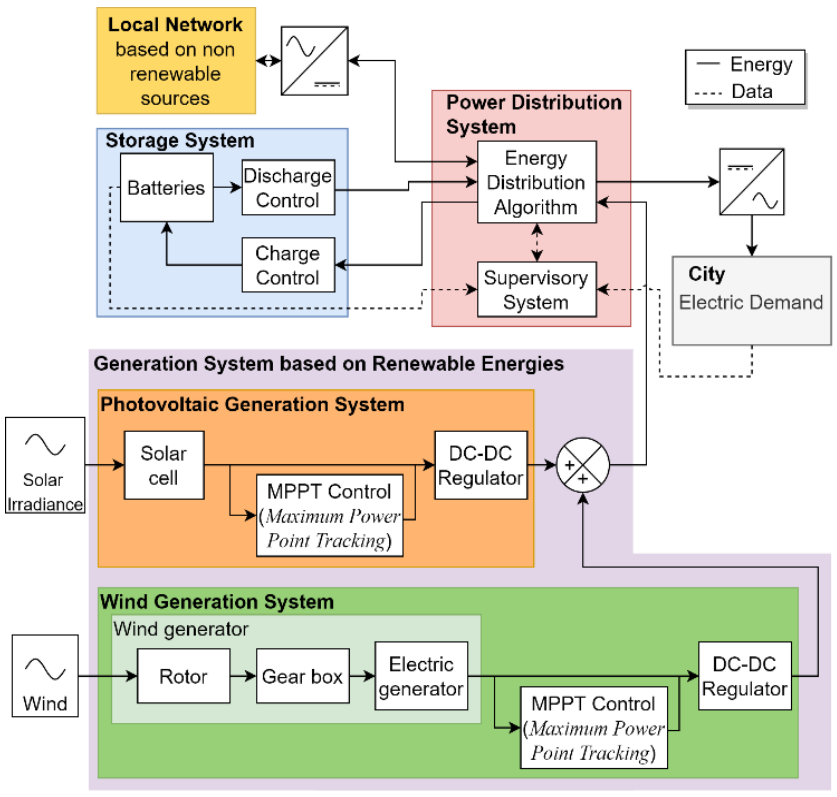

Fig. 1. Selected architecture, based on [21]

The development of the current work is founded on identifying the Data Science life cycle; it can be divided into eight steps according to [22], as Fig 2 shows. These eight steps can be summarized according to Fig 2 by overlapping the main four phases of the Data Analytics project proposed by [23].

The four phases of the Data Analytics project shown in Fig. 2 correspond to this work's methodological stages. Therefore, each of them will be defined and involved in sizing the chosen renewable energy system, as presented in the following sections.

\section{A. Preparation}

Following the ideas of [22], [23], the preparation phase leads to the problem understanding. It can be achieved through the definition of the challenge and the required data to solve it.
Therefore, it is possible to define a plan based on a hypothesis, identifying data sources, data acquisition, and selection.

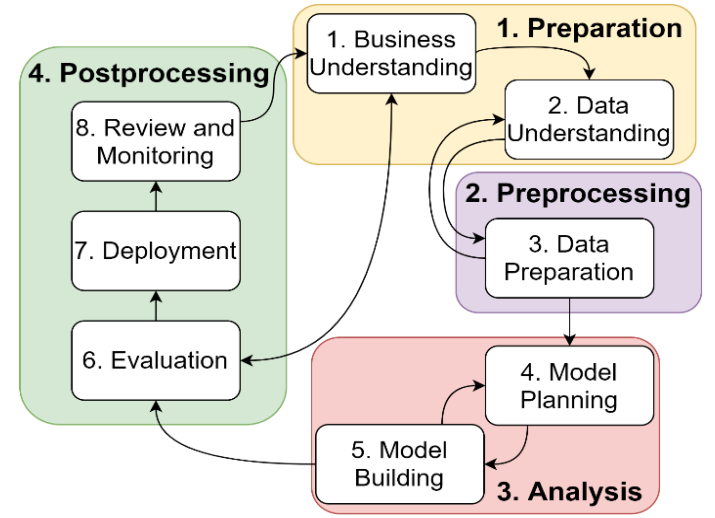

Fig. 2. The Data Science life cycle proposed by [22] overlapped with the Data Analytics phases proposed by [23]

In the context of this study, the preparation phase starts with understanding the required data for size the required amount of PV panels, wind turbines, and batteries. Hence, a deeper understanding of each system's mathematical models follows the models presented by [21]. It is possible to identify the related variables with this project. The global horizontal irradiance (GHI) and the wind speed are the climatic variables associated with the PV cells and the wind turbines. To size the system correctly, it is required to know the population's electric demand.

First, it is required to find a climatic database that includes the GHI and the wind speed to identify the chosen location's wind and photovoltaic potential. Databases like the Photovoltaic Geographical Information System (PGIS), NASA Surface Meteorology and Solar Energy Database, National Solar Radiation Data Base (NSRDB), IDEAM Atlas, Global Solar Atlas, Global Wind Atlas, and RETScreen were explored. Table I presents a summary of the data.

\section{TABLE I. DATABASE COMPARISON}

\begin{tabular}{|c|c|c|c|c|}
\hline Database & $\begin{array}{c}\text { Period } \\
\text { (Years) }\end{array}$ & $\begin{array}{c}\text { Sampling } \\
\text { Frequency }\end{array}$ & $\begin{array}{c}\text { Mean } \\
\text { daily } \mathbf{G H I} \\
\left(\mathbf{W} / \mathbf{m}^{2}\right)\end{array}$ & $\begin{array}{c}\text { Mean Wind } \\
\text { Speed }-\mathbf{1 0} \text { m } \\
(\mathbf{m} / \mathbf{s})\end{array}$ \\
\hline NSRDB & $1998-2017$ & 30 min & 5748 & 4.11 \\
\hline NASA & $1981-2019$ & Day & 5340 & 3.07 \\
\hline $\begin{array}{c}\text { Atlas } \\
\text { IDEAM }\end{array}$ & $2009-2014$ & Month & 6080 & 3.40 \\
\hline PGIS & $2005-2015$ & Hour & 5810 & 3.10 \\
\hline $\begin{array}{c}\text { Global } \\
\text { Solar Atlas }\end{array}$ & $1999-2015$ & Annual & 5610 & - \\
\hline $\begin{array}{c}\text { Global } \\
\text { Wind Atlas }\end{array}$ & $2001-2010$ & Annual & - & 4.07 \\
\hline RETScreen & $2001-2010$ & Annual & 5268 & 4.03 \\
\hline
\end{tabular}

Following the results of Table I, and taking as a priority a higher sampling frequency and the period of the data collection, the database that fits the requirements is the NSRD database. Also, this database shows good data quality on its inspection.

In contrast, the electric demand data was not found in any public database. Consequently, using a detailed report of the electric demand of the interest location [24] and the Monte Carlo simulation, it was possible to obtain a synthetic database 
simulating the electrical demand. This database considers a residential load of around 4000 homes, following the statistical assumptions made by [24]. A representation of the obtained Monte Carlo simulation data is presented in Fig 3.

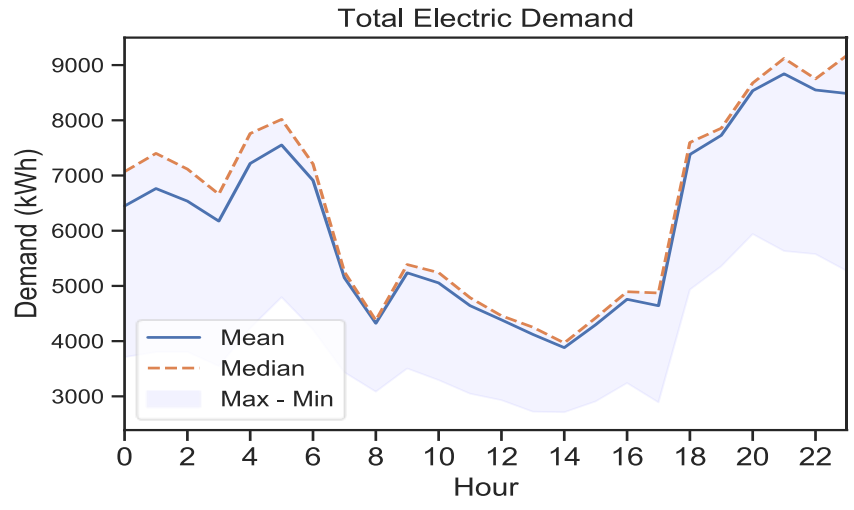

Fig. 3. Hourly Electric Demand obtained by Monte Carlo Simulation

\section{B. Preprocessing}

According to [22], [23], the preprocessing phase is characterized by activities that improve the collected raw data with tasks like data cleaning, filtering, correction, standardization, and transformation.

The preprocessing stage for the selected study begins with data gathering. Later, it was needed to merge the yearly datasets (20 years in total) sampled every 30 minutes provided by the NSRDB dataset. This merged dataset showed redundant information; as a result, the data were downsampled. The resampled dataset has an hourly sampling frequency; it reduced the dataset's size from 350400 to 175200 . The obtained dataset showed a data quality, apparently without outliers or invalid data.

\section{Analysis}

According to [22], [23], the Analysis phase is characterized by the exploratory analysis of the gathered data. If it is required the creation of a model, that should be evaluated according to relevant parameters. The Analysis phase applied in the context of this study will allow the data understanding. Consequently, it will lead us to the size of the renewable energy system.

First, it is possible to summarize the collected databases statistically, allowing the observation and identification of each dataset's main features presented in Table II.

TABLE II. DATA SUMMARY

\begin{tabular}{|c|c|c|c|}
\hline Description & $\begin{array}{c}\text { GHI } \\
\left(\mathbf{W} / \mathbf{m}^{2}\right)\end{array}$ & $\begin{array}{c}\text { Wind Speed - } \\
\mathbf{1 0 ~} \mathbf{~ ( m / s )}\end{array}$ & $\begin{array}{c}\text { Electric Demand } \\
(\mathbf{k W h})\end{array}$ \\
\hline Mean & 239.52 & 4.11 & 6150.67 \\
\hline Standard deviation & 321.43 & 1.55 & 1807.52 \\
\hline Minimum & 0.00 & 0.00 & 2712.10 \\
\hline 25th percentile & 0.00 & 3.00 & 4459.42 \\
\hline 50th percentile & 0.00 & 4.20 & 5386.96 \\
\hline 75th percentile & 492.00 & 5.30 & 7760.66 \\
\hline Maximum & 1061.00 & 8.80 & 9174.62 \\
\hline
\end{tabular}

Therefore, it is essential to identify the GHI's hourly behavior, wind speed, and electric demand. This information will help us to identify the hourly requirements of the system under study. Fig 4 shows the GHI's hourly behavior, where it is possible to observe the peak of irradiance at midday and a total absence of it between 18 and $5 \mathrm{~h}$. On the other hand, wind speed behavior is presented in Fig 5, where it is possible to observe the minimum wind speed around midday. Finally, the hourly electric demand was previously shown in Fig 3, where it was possible to identify a higher load after $18 \mathrm{~h}$, as it is expected in a residential zone.

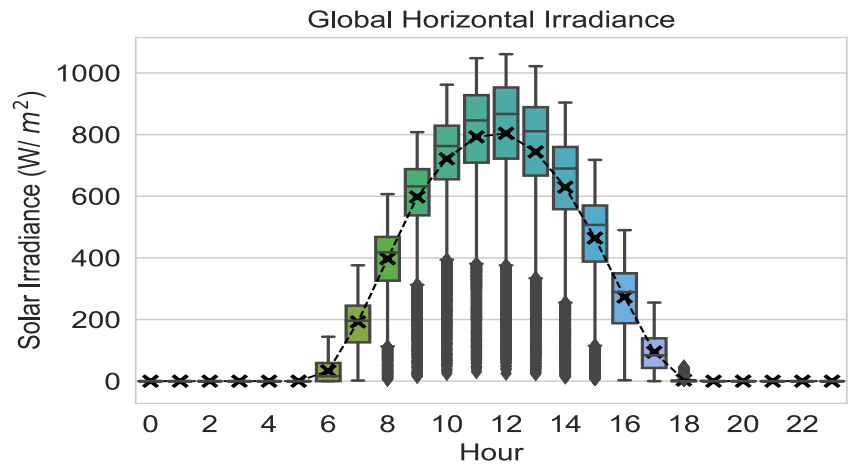

Fig. 4. Hourly GHI

Now it is possible to proceed with the sizing process of the renewable energy system, taking as reference the identified photovoltaic potential, wind potential, and the load requirements.

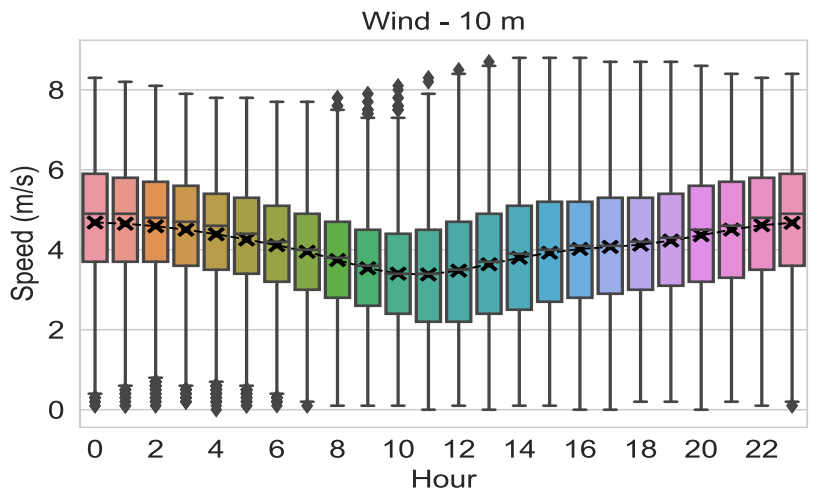

Fig. 5. Hourly Wind speed $(10 \mathrm{~m})$

The sizing process optimizes the energy price based on the Levelized cost of energy (LCOE). This cost function tries to maximize the diversity of energy sources. For the given study, the LCOEs calculated by [21] are $0.421 \mathrm{US} \$ / \mathrm{kWh}$ in onshore wind energy and $0.351 \mathrm{US} \$ / \mathrm{kWh}$ for photovoltaic energy. By the solution of this constrained problem is obtained the ideal distribution of renewable sources, $45,46 \%$ of wind energy $\left(P_{e}\right)$ and $54.53 \%$ of photovoltaic energy $\left(P_{S}\right)$, giving a total unitary $\mathrm{kWh}$ price of $0.383 \mathrm{US} \$ / \mathrm{kWh}$, being the value that balances the percentage costs between photovoltaic and wind sources.

In order to size the wind generation system, (1) is applied [21] based on the parameters detailed in Table III, where it was calculated the $E_{\text {need }}$ for one year or $8760 \mathrm{~h}$ taking into account the daily capacity of the wind energy $(\sim 148 \pm 44 \mathrm{MW})$. 


$$
P_{T}=\frac{E_{n e e d}}{C_{p} * \eta_{i n v} * 8760 h} * P_{e}=6.92 M W
$$

TABLE III. CONSTANT VALUES OF WIND POWER SYSTEM

\begin{tabular}{|c|c|l|}
\hline Symbol & Value & \multicolumn{1}{|c|}{ Meaning } \\
\hline$P_{e}$ & $45,46 \%$ & $\begin{array}{l}\text { Required wind energy percentage based on } \\
\text { total daily demand }\end{array}$ \\
\hline$E_{\text {need }}$ & $53.874 \mathrm{~kW}$ & Mean daily required energy (Table II) \\
\hline$C_{p}$ & 0,45 & Performance coefficient of the system \\
\hline$\eta_{\text {inv }}$ & 0,9 & Inverter Efficiency \\
\hline
\end{tabular}

The result of (1) shows that the wind generator needs to fulfill a requirement of $6.92 \mathrm{MW}$. Then, in the wind generator selection was possible to find the AGW 110 / 2.1 (tower $110 \mathrm{~m}$ high and capable of generating 2.1 MW of energy), made by WEG [25]. With this wind generator, it is possible to identify a need of 3.29 generators, which can be approximated to 3 , undersizing the system.

The photovoltaic system's sizing process is similar, but using (2)[21] and the data from Table IV. $E_{75 \%}$ is used as a data-driven safety factor to guarantee the projected amount of energy.

$$
E_{\text {need }}=\frac{E_{75 \%}}{\eta_{\text {batt }} * \eta_{\text {inv }}} * P_{s}=126.78 \mathrm{MWh}
$$

Table IV. Constant Values Of Solar Power System

\begin{tabular}{|c|c|l|}
\hline Symbol & Value & \multicolumn{1}{c|}{ Meaning } \\
\hline$E_{75 \%}$ & $186.240 \mathrm{~kW}$ & $\begin{array}{l}\text { Daily energy consumption of the } 75^{\text {th }} \\
\text { percentile (Table II) }\end{array}$ \\
\hline$\eta_{\text {batt }}$ & 0,89 & Battery Cell Efficiency \\
\hline$\eta_{\text {inv }}$ & 0,9 & Inverter Efficiency \\
\hline$P_{S}$ & $54.53 \%$ & Percentage of required photovoltaic energy \\
\hline$P_{M P P}$ & $510 \mathrm{Watts}$ & Cell peak power per cell \\
\hline$H P S_{\text {crit }}$ & $6,5 \mathrm{~h}$ & Peak times of the solar irradiance (Fig. 4) \\
\hline$P R$ & 0,9 & Overall performance factor \\
\hline$V_{\text {line }}$ & $11200 \mathrm{~V}$ & Line voltage defined for the system \\
\hline$V_{O C}$ & $66,31 \mathrm{~V}$ & Open-circuit voltage \\
\hline
\end{tabular}

The photovoltaic cells chosen are the TSH-S510 monocrystalline cells with 510 Watt-peak, according to [26]. With the necessary power for the photovoltaic panel, it is possible to identify the number of photovoltaic panels. Hence, (3), (4), and (5) are applied.

$$
\begin{gathered}
N_{\text {Total }}=\frac{E_{\text {need }} \text { v }}{P_{M P P} * H P S_{\text {crit }} * P R}=42493 \text { Cells } \\
N_{\text {series }}=\frac{V_{\text {line }}}{V_{O C}} \cong 169 \text { cells } \\
N_{\text {parallel }}=\frac{N_{\text {Total }}}{N_{\text {serie }}} \cong 251 \text { cells }
\end{gathered}
$$

A set of 169 cells in series and 251 in parallel were obtained through this procedure, totaling 42419 PV cells.

Finally, the storage system is calculated under an unfavorable condition of high demand and low generation, implying an oversizing of the storage system, guarantying its performance under normal circumstances. The chosen adverse electric generation condition corresponds to a low energy generation, represented by the 25 th percentile of the hourly wind speed (Fig 5) and GHI (Fig 4). On the other hand, the high demand condition corresponds to the electric demand's hourly 75th percentile (Fig 3).

Hence, it is required to verify the chosen photovoltaic cells' performance and wind generators to identify the lack of power the storage system needs to cover in the design with the given design scenario. For this purpose, it is mandatory to simulate the behavior of those systems under the given conditions.

The simulation process starts with adapting the climatic data of input to the project requirements. The GHI can be used as it is, but the gathered wind speed needs a modification. The wind speed data was collected on $10 \mathrm{~m}$ high, and according to the specifications of the chosen wind generators, the required wind speed corresponds to $110 \mathrm{~m}$ high. In the same direction, according to the NSRDB dataset, the gathered data corresponds to an approximation of the nearest meteorological station, in this case, the Ernesto Cortissoz Airport. Therefore, the wind speed values should be adjusted according to the terrain rugosity. The wind speed data is updated to the new requirements using the online rugosity conversion tool based on [27], [28], part of the parameters described in Table $\mathrm{V}$, and the equation of height variation provided by [27], shown in (6).

$$
v_{2}=v_{1} * \frac{\ln \left(\frac{h_{2}}{z_{0}}\right)}{\ln \left(\frac{h_{1}}{z_{0}}\right)}
$$

TABLE V. GENERAL VARIABLES OF THE WHOLE ARCHITECTURE

\begin{tabular}{|c|l|}
\hline Symbol & \multicolumn{1}{|c|}{ Meaning } \\
\hline$v_{1}$ & Wind speed at the current height \\
\hline$v_{2}$ & Wind speed at the desired height \\
\hline$h_{1}$ & Reference height \\
\hline$h_{2}$ & Desired height \\
\hline$z_{0}$ & Location roughness length \\
\hline$P_{w}$ & Power obtained in $\mathrm{kW}$ \\
\hline$V_{110}$ & Wind speed on $110 \mathrm{~m}$ \\
\hline$P_{f}$ & Photovoltaic system generated power \\
\hline
\end{tabular}

With the adjusted wind speed, it is possible to verify the wind generator and photovoltaic performances under the given conditions. The wind generator output power can be obtained from its datasheet [25], and it can approximate in (7) [21] with a Pearson correlation coefficient $\mathrm{R}^{2}$ of 0.992 .

$$
=\left\{\begin{array}{c}
0, P_{w}\left(V_{110}\right) \\
-0.0024 V_{110}^{6}-0.0353 V_{10}^{5}+1.2973 V_{110}^{4}-8.1474 V_{110}^{3}, \quad 2<V_{110}<12 \\
+35.637 V_{110}^{2}-46.142 V_{110}+3.881 \\
2100, \quad V_{110} \geq 12
\end{array}\right.
$$

In contrast, obtain the power generated by the photovoltaic cells can be more complicated. Still, it is possible to use the simulator developed by [21], under the given conditions, its behavior was approximated to (8), with a Pearson correlation coefficient $R^{2}$ of 1 .

$$
P_{f}(G H I)=\left\{\begin{array}{c}
0, \quad G H I \leq 0 \\
0,0772 G H I^{2}+20247 G H I+28194, \quad G H I>0
\end{array}\right.
$$

With the number of the photovoltaic cells and wind generators, its simulation models are given by (7) and (8), and the dataset that fulfills our needs is possible to identify the lack of power for the given study case and calculate the number of batteries required for this case study. Fig 6 shows the hourly 
difference between the input and output power under the given conditions; the negative values are the lack of energy and the positive, the surplus power.

Adding up the lack of energy in the proposed system, according to Fig 6, it is possible to identify a daily lack of power of $59.021 \mathrm{MW}\left(E_{\text {lack }}\right)$, what is what our storage system should supply. On the other hand, the surplus power corresponds to $60.051 \mathrm{MW}$, which will charge the storage system or can be used in the local grid for different purposes.

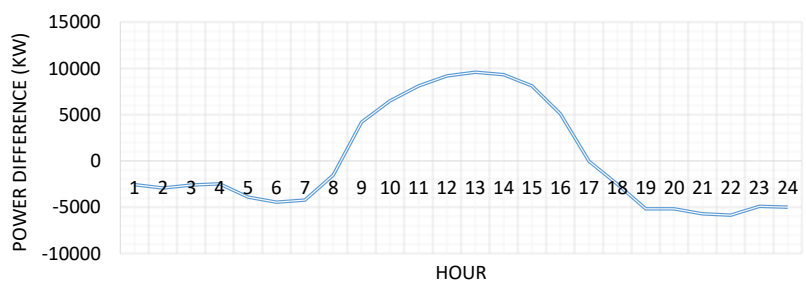

Fig. 6. The power difference between generated energy and demand

The storage system is calculated based on $E_{\text {lack }}$ value, using the criteria presented by [21], and the data from Table VI, leadacid batteries technology is used, following (9).

$$
C_{\text {ne }}=\frac{\frac{E_{\text {lack }} * F_{\text {sec }}}{P_{\text {DeepMax }}}}{V_{\text {BattL }}} \cong 14930 \mathrm{Ah}
$$

TABLe VI. Constant Values Of Battery Power System

\begin{tabular}{|c|c|l|}
\hline Symbol & Value & \multicolumn{1}{|c|}{ Meaning } \\
\hline$E_{\text {lack }}$ & $59,021 \mathrm{MWh}$ & Identified lack of power \\
\hline$C_{\text {ne }}$ & - & Battery nominal capacity \\
\hline$P_{\text {DeepMax }}$ & 0,6 & Maximum discharge depth \\
\hline$V_{\text {BattL }}$ & $11200 \mathrm{~V}$ & Line voltage of the storage system \\
\hline$F_{\text {sec }}$ & 1,7 & Arbitrary safety factor \\
\hline$P_{n}$ & $3000 \mathrm{Ah}$ & Hourly supplied Current \\
\hline$V_{\text {batt }}$ & $2 \mathrm{~V}$ & Battery voltage \\
\hline$\Delta T_{B}$ & - & $\begin{array}{l}\text { Difference between ambient and } \\
\text { current battery temperatures }\end{array}$ \\
\hline$S O C$ & - & Battery state of charge \\
\hline$I_{B}$ & - & Battery current \\
\hline
\end{tabular}

Consequently, it is possible to identify the number of batteries following (10) and (11).

$$
\begin{gathered}
B_{\text {Parallel }}=\frac{C_{n e}}{P_{n}} \cong 5 \text { Batteries } \\
B_{\text {Series }}=\frac{V_{\text {BattL }}}{V_{\text {batt }}}=5600 \text { Batteries }
\end{gathered}
$$

Where $P_{n}$ and $V_{\text {batt }}$ are inner constants of the selected batteries and were taken from [21]. From (10) and (11), it is possible to conclude that the needed storage system requires 28000 lead-acid batteries with $2 \mathrm{~V}$ and $3000 \mathrm{Ah}$, distributed as shown above.

Summarizing, the designed system has 3 wind generators with a capacity of $2.1 \mathrm{MW}$ and $110 \mathrm{~m}$ high, 42419 monocrystalline photovoltaic cells with 510 Watts-peak, and 28000 lead-acid batteries with $2 \mathrm{~V}$ and $3000 \mathrm{Ah}$.

\section{Postprocessing}

The postprocessing stage requires the evaluation of the developed models according to the chosen metrics. It is a documentation and communication phase, where the system's performance is monitored carefully [22], [23].

In this case study, the system's evaluation is done with simulation, including the models (7), (8), a battery charge/ discharge model, and a power distribution system, following Fig 1. The model of the hourly battery charge is presented in (12), and the discharge in (13); both models were obtained from [21].

$$
\begin{gathered}
V_{B}=[2-0.16 S O C]+\frac{I}{C_{10}}\left(\frac{6}{1+I_{B}^{0,86}}+\frac{0.48}{(1-S O C)^{1,2}}+0.036\right) *\left(1-0.025 \Delta T_{B}\right) \\
V_{B}=[2.085-0.12(1-S O C)]-\frac{I}{C_{10}}\left(\frac{4}{1+I_{B}^{1,3}}+\frac{0.27}{S O C^{1,5}}+0.02\right) \\
*\left(1-0.007 \Delta T_{B}\right)
\end{gathered}
$$

On the other hand, the power distribution system used in this stage corresponds to a simple flowchart that distributes the energy according to the storage system state of charge (SOC); the details of this flowchart are shown by [21].

Once the sizing of PWHS is obtained, the next step is to implement the whole architecture in a simulation platform, which in this case, is performed under the python environment. The system was tested under several conditions of our dataset, and it was possible to observe the system handles the demand sufficiently as expected. The behavior of the system during two random days is shown.

\section{a) The storage's SOC and its different states}

Fig 7 shows the storage's SOC, its different states (charge, discharge, and idle), and how the stored energy is managed. It also improves energy efficiency by not losing the excess of energy and using it as the architecture needs, which in other systems is dissipated.

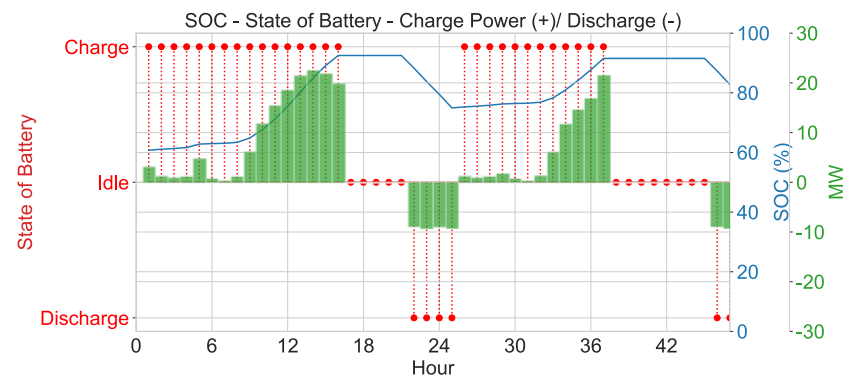

Fig. 7. The storage's SOC, system state, and charged/discharged power

\section{b) The Power in the System}

Fig 8 shows the power of the different parts of the system, and it is possible to identify the local grid's almost null need to support the city's demand. Fig 9 shows how the remaining power was managed in the storage system or the local grid (or other uses).

\section{DISCUSSION}

This work presented a data-driven sizing process for renewable energy systems. This proposal was introduced through the presentation of a case study in a given location. This proposal's methodology followed the most relevant Data Science and Data Analytics project life cycle stages, adapted to this area. The used process showed successful results based on the system's performance. 


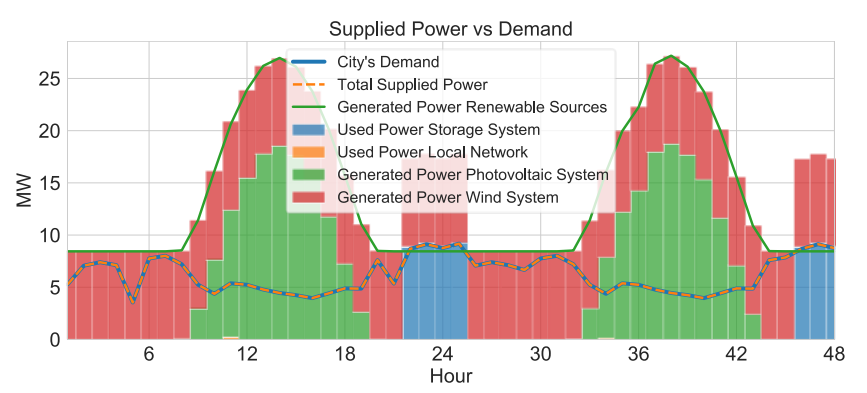

Fig. 8. Power in the system

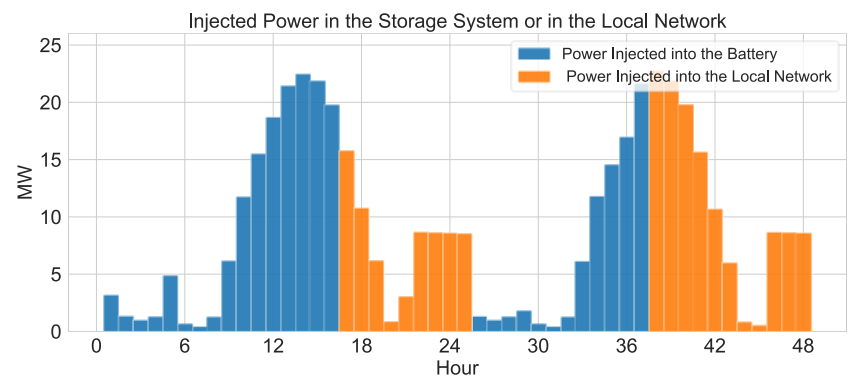

Fig. 9. The power difference between the generated energy and the demand

Some data-driven considerations were taken in this paper, like oversizing the system based on the gathered data, its statistics, and analysis. With high demand and low energy generation, the design scenario allowed us to make a data-driven scenario to take the best sizing considerations for the system, supported by the system's performance in Fig 7, Fig 8, and Fig 9.

The system's performance presented in Fig 7, 8, and 9 showed promising results and low dependence on external power sources. As expected, the system was oversized correctly. Consequently, it presented a surplus under average conditions; that can be used for other purposes out of residential usage.

\section{CONCLUSION AND FURTHER DEVELOPMENTS}

In conclusion, this work presented a well succeed example of a data-driven sizing approach for renewable energy systems, showing the feasibility and potential of the data in the context of renewable energies. The correct understanding of a specific area, like renewable energy systems as fair use and data analysis, was the key to facing this challenge.

This paper showed an application of data-driven processes that can be more popular in the short and medium-term due to the increasing usage of Big Data and the Internet of Things. Those technologies are related to bigger datasets, which will bring more opportunities to make more accurate data-driven decisions, as this work showed.

As further developments, this work can be compared with other sizing methods to identify the advantages and disadvantages of this approach and how a data-driven process can enhance other methods. Also, reinforcement learning can significantly improve the power distribution system, optimizing the overall system's performance.

\section{REFERENCES}

[1] U. S. E. I. A. EIA, "EIA projects $48 \%$ increase in world energy consumption by 2040," 2016.
[2] BP, "Statistical Review of World Energy," 2020.

[3] B. Singh and J. Sharma, "A review on distributed generation planning," Renew. Sustain. Energy Rev., vol. 76, no. March, pp. 529-544, 2017.

[4] K. Moslehi and R. Kumar, "A reliability perspective of the smart grid," IEEE Trans. Smart Grid, vol. 1, no. 1, pp. 57-64, 2010.

[5] T. Devezas, D. LePoire, J. C. O. Matias, and A. M. P. Silva, "Energy scenarios: Toward a new energy paradigm," Futures, vol. 40, no. 1, pp. $1-16,2008$.

[6] T. Ackermann, G. Andersson, and L. Söder, "Distributed generation: A definition," Electr. Power Syst. Res., vol. 57, no. 3, pp. 195-204, 2001.

[7] M. Di Somma et al., "Multi-objective operation optimization of a Distributed Energy System for a large-scale utility customer," Appl. Therm. Eng., vol. 101, pp. 752-761, 2016.

[8] O. Erdinc and M. Uzunoglu, "Optimum design of hybrid renewable energy systems: Overview of different approaches," Renew. Sustain. Energy Rev., vol. 16, no. 3, pp. 1412-1425, 2012.

[9] K. Anoune, M. Bouya, A. Astito, and A. Ben Abdellah, "Sizing methods and optimization techniques for PV-wind based hybrid renewable energy system: A review," Renew. Sustain. Energy Rev., vol. 93, no. May, pp. 652-673, 2018.

[10] P. Nema, R. K. Nema, and S. Rangnekar, "A current and future state of art development of hybrid energy system using wind and PV-solar: A review," Renew. Sustain. Energy Rev., vol. 13, no. 8, pp. 2096-2103, 2009.

[11] A. N. Celik, "Techno-economic analysis of autonomous PV-wind hybrid energy systems using different sizing methods," Energy Convers. Manag., vol. 44, no. 12, pp. 1951-1968, Jul. 2003.

[12] A. S. Al Busaidi, H. A. Kazem, A. H. Al-Badi, and M. Farooq Khan, "A review of optimum sizing of hybrid PV-Wind renewable energy systems in oman," Renew. Sustain. Energy Rev., vol. 53, pp. 185-193, 2016.

[13] S. S. Deshmukh and M. K. Deshmukh, "A new approach to micro-level energy planning-A case of northern parts of Rajasthan, India," Renew. Sustain. Energy Rev., vol. 13, no. 3, pp. 634-642, Apr. 2009.

[14] S. Sinha and S. S. Chandel, "Review of recent trends in optimization techniques for solar photovoltaic-wind based hybrid energy systems," Renew. Sustain. Energy Rev., vol. 50, pp. 755-769, 2015.

[15] R. Luna-Rubio, M. Trejo-Perea, D. Vargas-Vázquez, and G. J. RíosMoreno, "Optimal sizing of renewable hybrids energy systems: A review of methodologies," Sol. Energy, vol. 86, no. 4, pp. 1077-1088, 2012.

[16] J. Lian, Y. Zhang, C. Ma, Y. Yang, and E. Chaima, "A review on recent sizing methodologies of hybrid renewable energy systems," Energy Convers. Manag., vol. 199, no. April, p. 112027, 2019.

[17] C. Mekontso, A. Abubakar, S. Madugu, O. Ibrahim, and Y. A. Adediran, "Review of Optimization Techniques for Sizing Renewable Energy Systems," Comput. Eng. Appl. J., vol. 8, no. 1, pp. 13-30, 2019.

[18] Y. Zhang, T. Huang, and E. F. Bompard, "Big data analytics in smart grids: a review," Energy Informatics, vol. 1, no. 1, pp. 1-24, 2018.

[19] G. Escobedo, N. Jacome, and G. Arroyo-Figueroa, "Big data \& analytics to support the renewable energy integration of smart grids case study: Power solar generation," IoTBDS 2017 - Proc. 2nd Int. Conf. Internet Things, Big Data Secur., no. IoTBDS, pp. 267-275, 2017.

[20] M. Soto, T. Galoppo, and M. Jose, "Applying Data Science to Improve Solar Power Production and Reliability," no. October, pp. 1-12, 2017.

[21] J. A. Mora Montañez, "Gerenciamento, Produção e Controle de Potência para um Sistema Híbrido de Energia Renovável,” Universidade Estadual de Campinas (UNICAMP), 2020.

[22] I.-Y. Song and Y. Zhu, "Big Data and Data Science: Opportunities and Challenges of iSchools," J. Data Inf. Sci., vol. 2, no. 3, pp. 1-18, 2017.

[23] T. A. Runkler, Data Analytics. Wiesbaden: Springer Fachmedien Wiesbaden, 2016.

[24] María Camila Estrada Ocampo, Daniel Enrique Medrano Ahumada, and Vanessa Paola Quintero González, "ANÁLISIS DEL PERFIL DE CARGA ELÉCTRICA POR ESTRATO EN LA CIUDAD DE BARRANQUILLA," Barranquilla, 2018.

[25] WEG, “Aerogeradores AGW 110/2.1." WEG, Jaraguá do Sul, 2017.

[26] TopSun, "TOPSUN Catalogue." TopSun, Jeollanam, 2018.

[27] Danish Wind Industry Association, "Wind Speed calculator," 2003.

[28] World Meteorological Organization, Guide to Meteorological Instruments and Methods of Observation: Part I - Measurement of Meteorological Variables, no. 8. World Meteorological Organization, 2018. 